\title{
AboutTESOL in Context
}

Journal of ACTA, Australian Council of TESOL Associations

\section{ACTA statement}

TESOL in Context is a refereed journal with a wide target audience, both national and international. Readership includes TESOL / EAL professionals working in all sectors of education; universities, primary and secondary schooling, early childhood settings, adult migrant programs, vocational training, ELICOS and TESOL teacher education, both in Australia and internationally. Articles published in TESOL in Context typically examine the nexus between theory and practice.

\section{The aims of TESOL in Context are to:}

- provide professionals in the field with insights into TESOL issues in Australia and internationally

- contribute to the development of classroom expertise through dissemination of current research and thinking around TESOL.

For guidelines on length and presentation of items submitted to TESOL in Context, please consult the Notes for Contributors.

Copyright for all articles published in TESOL in Context is vested in the journal. Permission to publish articles elsewhere should be sought from the Editors.

\section{Please note}

Views expressed in contributions to TESOL in Context do not necessarily reflect those of ACTA.

\section{For this issue}

\section{Editor: $\quad$ Shem Macdonald La Trobe University, Victoria}

\section{For next issue (29/1)}

Co-Editor: Vincent Backhaus Indigenous Education and Research Centre, James Cook University, Queensland

Co-Editor: Henry Fraser ARC Centre of Excellence for the Dynamics of Language, Australian Capital Territory

Co-Editor: Shem Macdonald La Trobe University, Victoria

\section{Journal Coordinator for this Issue}

Carly Minett

tic@tesol.org.au

\section{Editorial board}

Russell Cross

Ester de Jong

Beverly Derewianka

Toni Dobinson Joseph Lo Bianco John Macalister

Paul Nation
The University of Melbourne University of Florida

The University of Wollongong Curtin University

The University of Melbourne Victoria University of Wellington Victoria University of Wellington 